Artikel Penelitian

\title{
CORRELATION OF RENOGRAM WITH CYSTATIN-C LEVELS AND CREATININE CLEARANCE IN MEASURING GLOMERULAR FILTRATION RATE
}

\author{
Aisyah Elliyanti ${ }^{1}$, Iskandar ${ }^{2}$, Syaiful Azmi $^{2}$
}

\begin{abstract}
Abstrak
Renogram ${ }^{99 m}$ Tc-DTPA (diethylenetriamine pentacetic acid) memiliki beberapa kelebihan dalam mengukur laju filtrasi glomerulus (LFG). Cystatin-c digunakan sebagai petanda biologik baru untuk memperkirakan LFG. Tujuan penelitian ini adalah untuk menentukan korelasi nilai LFG antara renogram dengan cystatin-c dan kliren kreatinin pada pasien dengan penyakit ginjal kronis (PGK). Subjek penelitian adalah pasien PGK stadium dua berdasarkan hasil estimasi LFG dengan rumus Cockroft-Gault. Pasien yang memenuhi kriteria diperiksa renogram, kadar kreatinin serum, cystatin-c dan klirens kreatinin.Rerata LFG dari 30 orang subjek yang diperiksa dengan renogram, cystatin-c, creatinine clearance, Cockroft-Gault's formula berturut turut adalah $64.96 \mathrm{ml} / \mathrm{min} / 1.73 \mathrm{~m}^{2}$ (SD 28.047), $53.37 \mathrm{ml} / \mathrm{min} / 1.73 \mathrm{~m}^{2}$ (SD 21.29), $58.09 \mathrm{ml} / \mathrm{min} / 1.73 \mathrm{~m} 2$ (SD 35.45), $46.00 \mathrm{ml} / \mathrm{min} / 1.73 \mathrm{~m} 2$ (SD 12.06). Korelasi antara renogram dengan cystatin-c dengan nilai $r=0.585$ dan $p=0.0007$, antara renogram dengan klirens kreatinin dengan nilai $r=$ 0.388 dan $p=0.03$ ) dan antara renogram dengan rumus Cockroft-Gault's dengan nilai $r=-$ 0.029 dan $p=0.87$. Pada penelitian ini didapatkan hasil korelasi yang lebih baik antara renogram dengan cystatin-c dari pada antara renogram dengan klirens kreatinin dan antara renogram dengan rumus Cockroft-Gault's. Lebih lanjut, cystain-c merupakan alternatif yang lebih baik untuk memperkirakan LFG jika metode pemeriksaan LFG yang mendekati teknik pemeriksaan yang ideal tidak tersedia.
\end{abstract}

Kata kunci: Formula Cockroft-Gault, Kreatinin klirens, Cystatin-c, Glomenular filtration rate, Renogram

\begin{abstract}
Renogram using ${ }^{99 m}$ Tc-DTPA (diethylenetriamine pentacetic acid) has advantages in the measurement of glomerular filtration rate (GFR). Serum cystatin-c was recently projected to be the new marker of estimated GFR. The aim of this study is to establish correlation between GFRs, derived from renogram with cystatin-c levels and creatinine clearances in chronic kidney disease patients. We put to study thirty consecutive stage two of chronic kidney disease patients assigned based on GFR estimation by Cockroft-Gault's formula, taking into account the serum creatinine. Cystatin-c and creatinine clearance were performed to determine of GFR and renogram was included in this study. A total of thirty subjects, the mean of GFRs were taken from renogram, cystatin-c, creatinine clearance, Cockroft-Gault's formula were $64.96 \mathrm{ml} / \mathrm{min} / 1.73 \mathrm{~m}^{2}$ (SD 28.047), $53.37 \mathrm{ml} / \mathrm{min} / 1.73 \mathrm{~m}^{2}$ (SD 21.29), $58.09 \mathrm{ml} / \mathrm{min} / 1.73 \mathrm{m2}$ (SD 35.45), 46.00 $\mathrm{ml} / \mathrm{min} / 1.73 \mathrm{~m} 2$ (SD 12.06) respectively. A correlation between renogram with cystatin-c $(r=$ 0.585 and $p=0.0007)$ and renogram with creatinine clearance $(r=0.388$ and $p=0.03)$ and renogram with Cockroft-Gault's formula ( $r=-0.029$ and $p=0.87)$. This study has shown that a better correlation between renogram with cystatin-c than with creatinine clearance or CockroftGault's formula. Furthermore, cystain-c would be better alternative method incase having problems to obtain a closest ideal methods for GFR.

Keywords: Cockroft-Gault's formula, Creatinine clearances, Cystatin-c, Glomerular filtration rate, Renogram

Afiliasi Penulis : 1. Nuclear Medicine Unit, 2. Department of Medicine Dr.M.Djamil Hospital/School of Medicine Andalas Padang Indonesia. Correspondence: Aisyah Elliyanti Nuclear Medicine Unit Dr.M.Djamil Hospital/School of Medicine Andalas. Jl.Perintis Kemerdekaan Padang 25127. Indonesia. Fax 62-751-40012. Phone: 62816350092. Email: aelliyanti@yahoo.com
\end{abstract}




\section{INTRODUCTION}

Chronic kidney disease become a major public health problem, increasing evidence shows that its adverse outcomes, such as kidney failures, cardiovascular diseases and premature deaths are preventable or delayed. Early stages of chronic kidney disease can be detected by laboratories testing,

Clinical diagnosis of chronic kidney disease should be established based on the presence of kidney damage and the level of function which is determined by glomerular filtration rate (GFR) [1]. The measurement of GFR has been proven to be one of the most valuable assessments of renal function. It is based on clearance concept of renal function. Inulin clearance is considered as the gold standard method in determine GFR. This method employs the constant intravenous infusion and bladder catheterization. However, its use is restricted in clinical practice [2-6]. Thus, a Cockroft-Gault's formula, taking into account the serum creatinine and creatinine clearance are commonly performed for estimating GFR and accepted by clinicians as a suitable method for assessing renal function. This formula has several limitations, such as slight tubular secretion or inability to determine a single kidney GFR or to evaluate GFR in acutely changing situations poses severe restriction in creatinine clearance ${ }^{[2]}$

Renogram, a radionuclide technique is widely used for calculation of overall GFR. This technique is simple and accurate. The complex of ${ }^{99 m \mathrm{~m} T c-}$ dietylene triamine penta-acetic acid ( ${ }^{99 m}$ Tc-DTPA) is used as agent of choice when quantification of GFR is desired in association with renal imaging [2,6]. This technique is most useful in patients whom the urine collection is difficult, poorly cooperative patients and children. Another advantage of this technique is its ability to determine a single kidney GFR. [2-7]

In addition, cystatin-c was recently projected as the new marker for GFR determination. It is a new endogenous marker, particularly in patients with moderate to severe kidney damage. It fulfills numerous criteria that would make it suitable as a GFR marker. It is also closest ideal marker among available of endogenous marker [8-10]. The aim of this study was to establish a correlation of between GFR derived from renogram, cystatin-c levels and creatinine clearance and Cockroft-Gault's formula in chronic kidney disease patients.

\section{METHODS}

Thirty consecutive of stage two chronic kidney disease patients were studied. The stage of chronic kidney disease was established based on GFR estimation by Cockroft-Gault's formula, the serum creatinine levels should be within a range of $1.2-2.0 \mathrm{mg} \%$ or at least 3 months. Serum creatinine was measured by auto analyzer with Jaffe reaction method.

GFRs were determined from renogram, cystatin-c levels and creatinine clearance. Renogram was performed using a single head camera and subjects were hydrated with $500 \mathrm{ml}$ of water 30 minutes prior to examination. The subjects were laid down on the bed in a supine position. A dose of $150-200$

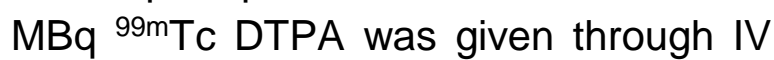
administration. The syringe with straight 
needle was counted by gamma camera prior and post injection in the same way. Region of interest (ROI) over each kidney was generated by the sum-frame of 1 to 3 minutes following injection. The semilunar ROI of background below each kidney was defined. GFR was automatically estimated according to Gates' algorithm. The results were normalized to $1.73 \mathrm{~m}^{2}$ body surface areas. Serum cystatin-c was measured from the blood samples and creatinine clearance was calculated from 24 hours urine samples. All subjects were given the informed consent.

All results are given as mean and standard deviation. Pearson's correlation analysis was used to correlate GFRs results were derived from renogram, cystatin-c, creatinine clearance and Cockroft-Gault's formula. T test was used for analysis. Sensitivity, specificity, positive predictive value, negative predictive value and accuracy were studied by receiver-operating characteristic (ROC) plots. The limits of agreement were analyzed using approach of Bland and Altman [11].

\section{RESULTS AND DISCUSSION}

A total of 30 subjects, 21 males and 9 females were included in this study, mean of age 60.8 years old. The underlying diseases were hypertension in 13 subjects and diabetes 17 subjects. Table 1 describe subject characteristics.

The mean of GFRs were derived from renogram, cystatin-c, creatinine clearance and Cockroft-Gault's formula were $64.96 \mathrm{ml} / \mathrm{min} / 1.73 \mathrm{~m}^{2}$ (SD 28.047), $53.37 \mathrm{ml} / \mathrm{min} / 1.73 \mathrm{~m}^{2}$ (SD 21.29), 58.09 $\mathrm{ml} / \mathrm{min} / 1.73 \mathrm{~m}^{2}$ (SD 35.45) and 46.00 $\mathrm{ml} / \mathrm{min} / 1.73 \mathrm{~m}^{2}$ (SD 35.45) respectively.
Table 1: Subjects Characteristic

\begin{tabular}{lcc}
\hline & Mean & $\begin{array}{c}\text { Standard } \\
\text { deviation }\end{array}$ \\
\hline Age (years) & 60.8 & 5.56 \\
$\begin{array}{l}\text { Body } \\
\text { weight (Kg) }\end{array}$ & 60 & 21 \\
Height (cm) & 158.7 & 12 \\
$\begin{array}{l}\text { Cystatin-c } \\
\text { (ml/min) }\end{array}$ & 53.37 & 21.29 \\
$\begin{array}{l}\text { Creatinine } \\
\text { clearance } \\
\text { (ml/min) }\end{array}$ & 58.09 & 35.45 \\
$\begin{array}{l}\text { Serum } \\
\text { creatinine } \\
\text { (mg\%) }\end{array}$ & 1.46 & 0.22 \\
\hline
\end{tabular}

The GFR of renogram did not pose significance in value from that obtained using cystatin-c $(\rho=0.07)$ and creatinine clearance $(\rho=0.4)$. In contrast, the results of Cockroft-Gault's formula were significant differences with renogram $(\rho=0.002)$. The Correlation between renogram with cystatin-c was $r=0.585$ and $\rho=0.0007$, renogram with creatinine clearance was $r=0.388$, $\rho=0.03$, and renogram with CockroftGault was $r=-0.029, \rho=0.87$.

ROC curves were analyzed for cystatin-c, creatinine clearance and Cockroft-Gaults formula. A cystatin-c cut-off levels of $58.04 \mathrm{ml} / \mathrm{min} / 1.73 \mathrm{~m}^{2}$ with sensitivity of $88.24 \%$ and specificity of $69.23 \%$, for creatinine clearance this was $47.15 \mathrm{ml} / \mathrm{min} / 1.73 \mathrm{~m}^{2}$ for sensitivity of $58.82 \%$ and specificity $84.62 \%$ and for Cockroft Gault's formula results a cutoff was $44.37 \mathrm{ml} / \mathrm{min} / 1.73 \mathrm{~m}^{2}$ for sensitivity of $58.82 \%$ and specificity of 
$69.23 \%$. The ROC curves analyzed are presented in table 2 .

Table 2: Diagnostic values of GFR Measurement methods

\begin{tabular}{lccc}
\hline & Cys & CC & CG \\
\hline Sensitivity & $88.24 \%$ & $58.82 \%$ & 58.82 \\
Specificity & $69.23 \%$ & $84.62 \%$ & $69.23 \%$ \\
& & & \\
PPV & $78.9 \%$ & $83.3 \%$ & $71.4 \%$ \\
& & & \\
NPV & $81.8 \%$ & $61.1 \%$ & $56.3 \%$
\end{tabular}

Accuracy $\quad 74.4 \% \quad 68.3 \% \quad 56.6 \%$

Cys $=$ Cystatin-cs, CC $=$ Creatinine Clearance, $C G=$ Cockroft-Gault's, PPV=Positive Predictive Value, NPV=Negative Predictive Value

Bland-Altman plots for renogram and other methods of GFR measurement showed comparable scatter around the line of identity (Fig 1.A-C). The mean differences between renogram and cystatin-c was $11.6 \mathrm{ml} / \mathrm{min} / 1.73 \mathrm{~m}^{2}$ with limits of agreement (mean $\pm 2 S D$ ) of +57.2 to $-34 \mathrm{ml} / \mathrm{min} / 1.73 \mathrm{~m}^{2}$, for renogram and creatinine clearance and Cockroft-Gault's formula were 6.9 $\mathrm{ml} / \mathrm{min} / 1.73 \mathrm{~m}^{2}$ with limits of agreement $($ mean $\pm 2 S D)$ of +76.8 to -63 $\mathrm{ml} / \mathrm{min} / 1.73 \mathrm{~m}^{2}$ and $18 \mathrm{ml} / \mathrm{min} / 1.73 \mathrm{~m}^{2}$ with limits of agreement (mean $\pm 2 \mathrm{SD}$ ) of +78.4 to $-42.5 \mathrm{ml} / \mathrm{min} / 1.73 \mathrm{~m}^{2}$ respectively. (Figure $1 \mathrm{~A}, \mathrm{~B}$ and $\mathrm{C}$ ).

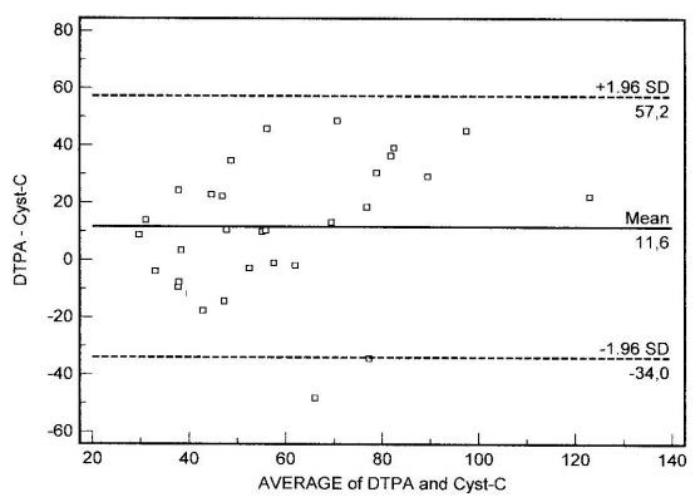

A

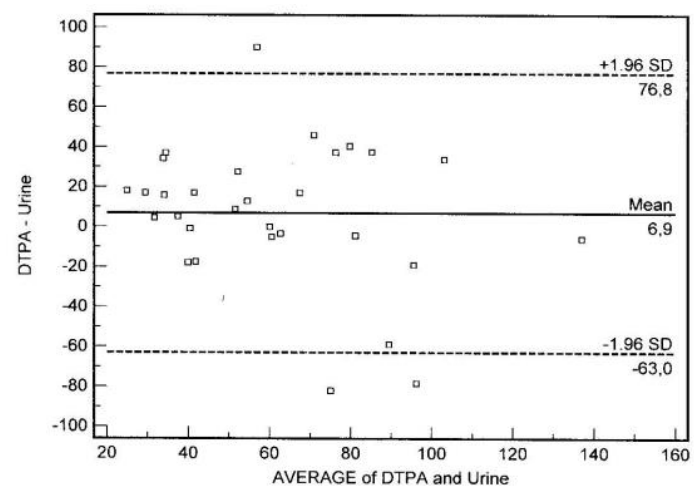

B

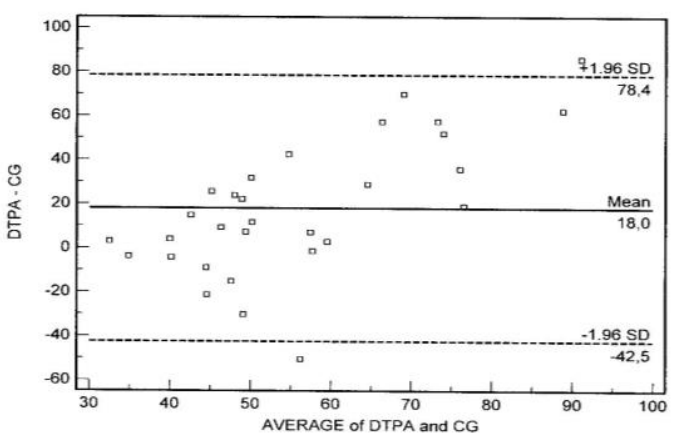

C

Figure 1: Limits of agreement between renogram with cystatin-c $(A)$, renogram with creatinine clearance $(B)$ and renogram with Cockroft-Gault's formula (C)

The close correlations between the plasma clearance of ${ }^{51} \mathrm{Cr}$-EDTA and 99mTc DTPA with renal clearance of inulin, justify the use of single injection of these materials to asses a GFR $[6,8]$. 
Renogram, a radionuclide technique which using a complex of ${ }^{99 \mathrm{~m} T \mathrm{~T}-}$ DTPA for quantification of GFR, is desired in association with renal imaging [6]. This method is most useful in patients whom the urine collection is difficult, poorly cooperative patients, children and the ability to asses a single kidney GFR and do not require urine collection ${ }^{[7,12] \text {. }}$

Serum creatinine is a crude marker of GFR and the most widely used measured of GFR [1]. Serum creatinine typically varies slightly from day to day, age and gender associated differences in creatinine production are proportional to muscle mass and creatinine generation can vary significantly in a given individual over time when muscle mass changes. It does not increase until renal function decrease up to $50 \%$ [8]. Tubular secretion of creatinine varies not only within an individual but also between individuals and the proportion of a total renal creatinine excretion attributable to tubular secretion increases with decreasing renal function. The latter further amplifies the overestimation of GFR represents ${ }^{[1,10,13] \text {. }}$

The Cockroft-Gault's formula provides a more accurate estimate of GFR than serum creatinine alone. It equation was developed in a sample of men and correction factor for women was proposed and requires measurement of body weight. The formula was developed to estimate creatinine clearance, therefore it overestimates GFR. Measurement of creatinine clearance using 24 hours urine samples is inconvenient and doest not improve the estimation of GFR over that provided by prediction equations [1]. Our results confirm the accuracy of creatinine clearance was $68.3 \%$ and Cockroft-Gault's formula was $56.6 \%$. The rather disappointing results were mainly related to serum creatinine level did not increase until renal function decrease up to $50 \%$ of its normal value and creatinine clearance is influenced by several covariates.

Cystatin-c was recently projected as the new marker for GFR determination. It is produced at a constant rate by all nucleated body cells [14]. Several studies indicate that its elimination from the circulation is almost exclusively by glomerular filtration. Renal plasma clearance of radionated cystatin-c was determined to $94 \%$ of ${ }^{51} \mathrm{Cr}$-Ethylene diamine tetra-acetic acid $\left({ }^{51} \mathrm{Cr}\right.$-EDTA) clearance in intact rats [15]. Studies in adults have shown cystatin-c to be more sensitive marker of changes in GFR than serum creatinine [16]. Our results indicate that the difference between mean of cystatin-c with renogram is not significant. There is a better correlation between renogram with cystatin-c $(r=$ 0.585 and $p=0.0007)$ compared with creatinine clearance $(r=0.388$ and $p=$ 0.03 ) and Cockroft-Gault's formula ( $r=$ 0.029 and $p=0.87$ ). The sensitivity and specificity of cystatin-c was comparable with data publish by Arend Bökenkamp et al ${ }^{[9]}$

The correlation between renogram with cystatin-c is considerably better than with creatinine clearance and Cockroft-Gault's. By contrast, all methods described a wide interval differences using a Blant-Almant analysis. This is reflecting the small sample size and the great variation of differences.

Some drawbacks of this study are a limited sample sizes, a narrow variety of patients and no standardization of 
creatinine measurement has established, thus considerable differences in diagnostic accuracy may be found between different assays. Therefore, further studies are required to improve the diagnostic performance.

\section{CONCLUSION}

This study has shown that a better correlation between renogram with cystatin-c than with creatinine clearance or Cockroft-Gault's formula. Furthermore, cystain-c would be bettter alternative method incase having problems to obtain a closest ideal methods for GFR determination in patients with mild and moderate stage of chronic kidney disease. However, none of these methods can replace the inulin clearance.

\section{REFERENCES}

1. Clinical Practice Guidelines for Chronic Kidney Disease: Executive Summary,2002. available at : http://www.kdogi.org

2. Gates GF. Glomerular Filtration. In: Henkin RE,editor. Nuclear Medicine. Philadelphia: Mosby Elsvier;2006.p.10241034

3. Bubeck B. Quantitative evaluation of clearance. In: Murray IPC, Ell PL, editor. Nuclear medicine in clinical diagnosis and treatment. London: Churchill Livingstone; 1998. p. 245-54.

4. Itoh K. Single-sample and gamma camera methods for determination of the glomerular filtration rate with tc-99m DTPA. Ann Nucl Med. 2002;16(8):541-8.

5. Itoh K. Comparison of methods for determination of glomerular filtration rate: tc99m-DTPA renography, predicted creatinin clearance method and plasma sample. Ann Nucl Med. 2003;17:561-5.
6. Biggi A, Viglietti A, Farinelli MC, Bonada C, Camuzzini. Estimation of glomerular filtration rate using chromium-51 ethylene diamine tetra-acetic and technetium-99m DTPA. Eur J Nucl Med. 1995;22:532-6.

7. Dass C. Radionuclide evaluation of renal function. Joint program in nuclear medicine. 1997. http://www.med.harvard.edu

8. Tan GD, Lewis AV, James TJ, Altmann P, Taylor RP, Levy JC. Clinical Useful of Cystatin $\mathrm{C}$ for the Estimation of Glomerular Filtration Rate in Type 1 Diabetes. Diabetes Care.2002:25:2004-2009.

9. Bökenkamp A, Domanetzki $M$, Zinck $R$, Schumann G, Byrd D, Brodehl J. Cystatin CA New Marker of Glomerular Filtration Rate in Children Independent of Age and Height. Pediatrics.1998:101:875-881

10. Filler G, Priem F, Lepage N, Sinha $P$, Vollmer I, Clark H, et all. Clinical Chemistry .2002:48:729-736

11. Bland JM, Almant DG. Statistical methods for assessing agreement between two methods of clinical measurement. Lancet. 1986;i:307-10.

12. Payne RB. Creatinine Clearance and Glomerular Filtration Rate.Ann Clin Biochem.2000;37:98-99

13. Poge U, Gerhardt T, Wagner BS, Klehr HU, Sauerbruch T, Woitas RP: Calculation of Glomerular Filtration Rate Based on Cystatin C in Cirrhotic Patients. Nephrol Dial Transplant.2006:21:660-664

14. Abrahamson M, Olafsson I, Palsdottir A,et all. Stucture and expression of the human cystatin C gene.Biochem J.1990;268:287294

15. Tenstad O, Roald AB, Grubb A, Aukland K. Renal handling of radiolabelled human cystatin $\mathrm{c}$ in the rat. Scand J Clin lab invest.1996;56:409-414

16. Newman DJ, Thakkar H, Edwards RG, et al. Serum cystatin $\mathrm{C}$ measured by automated immunoassay. A more sensitive marker of changes in GFR than serum creatinine. Kidney Int.1995:47:312-318 